\author{
Alina Holovatiuk \\ deppyjo1212@gmail.com \\ Master of science in architecture, PhD student, Kyiv National University of Construction \\ and Architecture, Faculty of Architecture, IT in Architecture Department
}

\title{
Memes in public urban spaces
}

\section{Memy w publicznych przestrzeniach miejskich}

\begin{abstract}
This article deals with the issue of creating memes in public urban spaces. The definition of the concept of the point of meaning, the object-symbol, the meme in architecture, their purpose and functions, and the process of their formation is described with the addition of illustrative materials. The article shows the approach of organising temporary public spaces with the help of symbolic objects for the revival of surrounding streets and public spaces, promoting pedestrian movement; this, in turn, can accelerate business activity and attract attention to outdoor life in the surroundings. Theoretical conclusions as well as a proposed project for a meme in the Gran San Blas area, Madrid, Spain to make economically sound changes and saturate the park to turn the neutral existing space into a more welcoming area.
\end{abstract}

Keywords: object-symbol, point of meaning, meme, urban environment, urban public space

\section{Streszczenie}

Artykuł porusza kwestię tworzenia memów w publicznych przestrzeniach miejskich. Definicja pojęcia punktu znaczeniowego, obiektu-symbolu, memu w architekturze, ich celu i funkcji oraz procesu ich powstawania została opisana przez dodanie materiałów ilustracyjnych. W artykule przedstawiono podejście do organizowania tymczasowych przestrzeni publicznych za pomocą obiektów symbolicznych na rzecz ożywienia otaczających ulic i przestrzeni publicznych, promując ruch pieszy; to z kolei może przyspieszyć działalność gospodarczą i zwrócić uwagę na życie na zewnątrz w otoczeniu. We wnioskach przedstawiono proponowany projekt mema w rejonie Gran San Blas w Madrycie, Hiszpania, aby dokonać ekonomicznie rozsądnych zmian i nasycić park oraz zmienić neutralną przestrzeń w bardziej przyjazną.

Słowa kluczowe: obiekt-symbol, punkt znaczeniowy, mem, środowisko miejskie, przestrzeń publiczna miasta 


\section{INTRODUCTION}

There are two main ways of transferring information - with the help of a gene pool and with the help of a meme pool. If the gene pool is responsible for replicating the genetic information contained in DNA, the meme pool considers memes as units of cultural information that are transmitted from individual to individual through external manifestations (artifacts) such as oral and written words, musical sounds, visual images, architectural styles, facial expressions and gestures, etc. The concept of the meme and the term itself were firstly proposed by evolutionary biologist Richard Dawkins in 1976 in the book 'The Selfish Gene'1.

In order for cultural innovations to evolve into a meme, it must withstand competition from other novelties, be repeated through imitation from one person to another, and be written down for further study by descendants. Philosopher J. Derrida argued that all artificially created things for the transmission of certain cultural information constitute a text consisting of signs, and are able to convey meaning ${ }^{2}$. In architecture, elements of cultural information that convey value may be the arch, capital, column, obelisk, etc. which are of paramount importance at the moment of creation and continue to transmit a certain value to the present day.

Throughout the genesis of each city, typologies of buildings and spaces have been created. These typologies have left their imprint on the city's life and dynamics and affect it to this day. The intensification of urbanisation and digitisation lead to social changes with increasing speed - the influence of memes (cultural renewal) dominate over the influence of genes (inherited code). The rapidly changing conditions associated with continuous mutations in the social structure (forms of human interaction), climatic and economic conditions require the development of urban spaces that can quickly adapt and reboot themselves under the next changes of memes. More and more often, we consider dynamic form-building and bioimitative architecture $^{3}$ as the future principles of the creation of architectural environments. Modern architecture is looking for a solution to ensure a long existence, not just copying natural forms, but understanding and being guided by the rules that underlie these forms.

Rapid scientific and technological progress and tools such as digital production, computational design ${ }^{4}$, virtual and augmented reality, artificial intelligence and synthetic biology ${ }^{5}$ give us the ability to transform cities in such a way that they can respond to user needs by adapting to change. The ability to identify sustainable memes of architectural urban space and cultural units that evolve over time, combined with the development of technology, provide a push to understand the future of cities as evolutionary organisms capable of responding in real time.

If we look on architectural urban public space from the side of progressive biology, then in specific conditions (natural, climatic, social, cultural, economic, etc.), it acts as a meme complex and sets a certain kit of behavioural models of the population (for the 
group or the people as a whole), among which, only the smaller part dominates and is subject to replication. The collaboration of such sciences as architectural phenomenology ${ }^{6}$, physiology, humanistic psychology, gestalt psychology and behavioural economics ${ }^{7}$ provide an opportunity to get a synergetic approach to the formation of principles and techniques for transforming the architectural public spaces of the future from the 'human factor' point of view.

The architectural public space bears witness to the main events in the city and the driving force for its development. It is the interaction between people in public space, its intensity and quality that pushes, guides or stops the progress of the city. The possibility or impossibility of contact with other people and with space sets a certain charge, provokes emotions and directs behaviour. In conditions of constant change in culture and ideology, acceleration of the pace of life, the introduction of innovative technologies, globalisation and the existence of a separate virtual public space on the Internet, there is a need to create interactive, easily implemented, low-cost and temporary facilities in real public space. Such object-symbols will be able to attract more attention than the capital buildings and structures, which require more time, energy and money.

\section{PURPOSE OF WORK}

The purpose of this article is to show the principles and methods of transformation of architectural public spaces in the context of ecologically, socially and nationally stable units of modern culture (memes). Thie article also identifies trends and provides a forecast for the emergence of new cultural units and their impact on the change of architectural public spaces in the context of the rapid development of social and technical networks, environmental sustainability, smart cities and human behaviour problems in urban space, using the example of the city of Madrid.

The government of Madrid has laid the foundations for a positive transformation of the country lasting until 2030. The positive inculcations into culture are best implemented through the use of architectural public spaces - the largest manipulator in society. The article shows a simple yet effective way to transform an empty public space into a humanfriendly public space with the addition of object-symbols to it.

\section{MATERIALS AND METHODS}

The proposed project and the testing of the theory of forming a meme in public space in Madrid was carried out after investigation, surveys and pre-project studies using comparative analyses, generalisation, and theoretical modelling. 


\section{RESULTS AND DISCUSSION}

Unlike 'first place' (home) and 'second place' (work), 'public space' (third place) ${ }^{8}$ is unstable and unpredictable. The interaction scenario in the first two places can be repeated each time with a small difference (due to the mixing of almost the same number of people, limited space and an unchanged set of functions). The script of the public space of the city, by contrast, tends to drastically change during the course of the day, on weekdays and weekends, depending on the time of year. All the time, new people come with positive or negative energy, pursuing different goals and acting differently.

In order to bring stability to the chaos of publicity, points of meaning are established in space. They are presented in the form of physical objects and convey a certain message - this message is: how to behave, how to perceive the surrounding reality, how to react, where to look or not to look, an indication of the direction of movement. The points of meaning that do not leave indifferent a large number of people, accent, dominant and cause additional emotions and stable associations with a certain place, grow into objects-symbols. At this stage, the value enclosed in the object by the author is not necessarily direct hyperbolisation or metaphorisation is possible. The public perceives and interprets the meaning of the object in its own way, it gets accustomed or is criticised. When information about such an object spontaneously spreads and goes beyond local information, and it is partially or completely copied, a new meme will be created. It is the approval of people, the recognition of the point of meaning and its replication that will turn it into a meme ${ }^{\text {. }}$

On the example of temporary public spaces such as public squares, distributed in North America (e.g. San Francisco, Philadelphia, New York), thanks to the points of meaning of the section of the roadway that are not being used, they are converted into public places for residents of surrounding buildings and worker enterprises. Like parklets, temporary public spaces are the result of a successful partnership between the city and the community of residents or the business association. Although work on public areas, from the intermediate stage to the final reconstruction, continues for 3-5 years, the interim plaza allows society to gain support and benefit from the public space in the short term, even before capital construction (Fig. 1) ${ }^{10}$.

Points of meaning in interim plazas are determined in the first place by their functional purpose. To prevent access of cars, the ban on parking bollards, massive fixed objects, such as granite blocks and containers for plants, road markings (double white stripes) are used in the plazas; these convince the pedestrian of the safety of the area, despite the fact that the activity takes place on the carriageway.

The meaning of moving, folding tables and chairs - the internal filling of temporary public spaces - to ensure flexible use of the space and to limit costs. Both the street furniture and the asphalt coating itself are painted in bright colours to make the space attractive and noticeable from a distance. 
Additional points of meaning with the possible transformation of them into symbol objects are the art of installation, market, performances, retail outlets. Their main task is to attract and promote local masters, to develop business and to activate society.

Temporary public areas are filled with objects made from inexpensive, wear-resistant materials, such as epoxy gravel, paint and thermoplastic. Climatic factors in the choice of specific materials and their durability are in the foreground.

A site for designing and testing the theory of forming a meme in public space was chosen by the author. This was an urban environment of the micro-district of Gran San Blas in the city of Madrid. The main task, which stood at this stage, was to offer facilities that revitalised and functionally enriched the low-maintenance territory of the park. In general, the idea of restoring the urban environment included improving the welfare of residents and increasing the attractiveness of the area for young families, taking into account a sustainable approach to the reconstruction process ${ }^{11}$.

Three zones were organised for the park: an active recreation zone, a zone of cultural and social activity, a passive zone with places for sitting and seclusion (Fig. 2).

The main principles of the new park layout: preservation of all trees; preservation of the main entrances to the park with the possibility of supplementing them; replacement of the coating; improving accessibility. Points of sense that need to be added to the planning of the park are the elements of improvement, namely: semicircular benches and tables, ordinary benches, portable seat-plates, lanterns and urns. The memes of the park are an installation 'Board of Wishes' and public art 'Tape of Infinity of Cognition' (Fig. 3).

Both elements contain curvilinear forms and are interactive. They focus on themselves. The uniqueness of the reception of the expression of opinions and the wishes of visitors, and the possibility of cultural enrichment turns both objects into iconic objects both for the park and for the area - into symbolic objects. And their popularity and the possibility of replication in other places - in memes.

An artificial stream unites three park areas, provides a pleasant sound, a fresh smell in space, and, in the hot climate in Madrid, it is a source of cooling. Together with the fountain, they are also object-symbols introduced in the territory, so that this park is associated with the opportunity to get cool by local residents.

\section{CONCLUSIONS}

To sum up, points of meaning, object-symbols, and memes are possible for use under any conditions of the initial state of the physical space, its resource support, with any budget and the possibilities of involving the local population, government structures and designers. Moreover, with small investments, easy installation and flexibility, modern architectural memes can have a large impact on both the local community and the attractiveness of the region as a whole. 
At the site used for verifying the formation of the meme in the western part of the Rehas area on the territory of Gran San Blas, Madrid, it was proposed to make economically sound changes and fill the park with objects required to turn the empty existing space into a functionally active area. The project received positive reviews from local residents and confirmed the effectiveness of this theory. It is recommended for further implementation as well as for further investigation. 


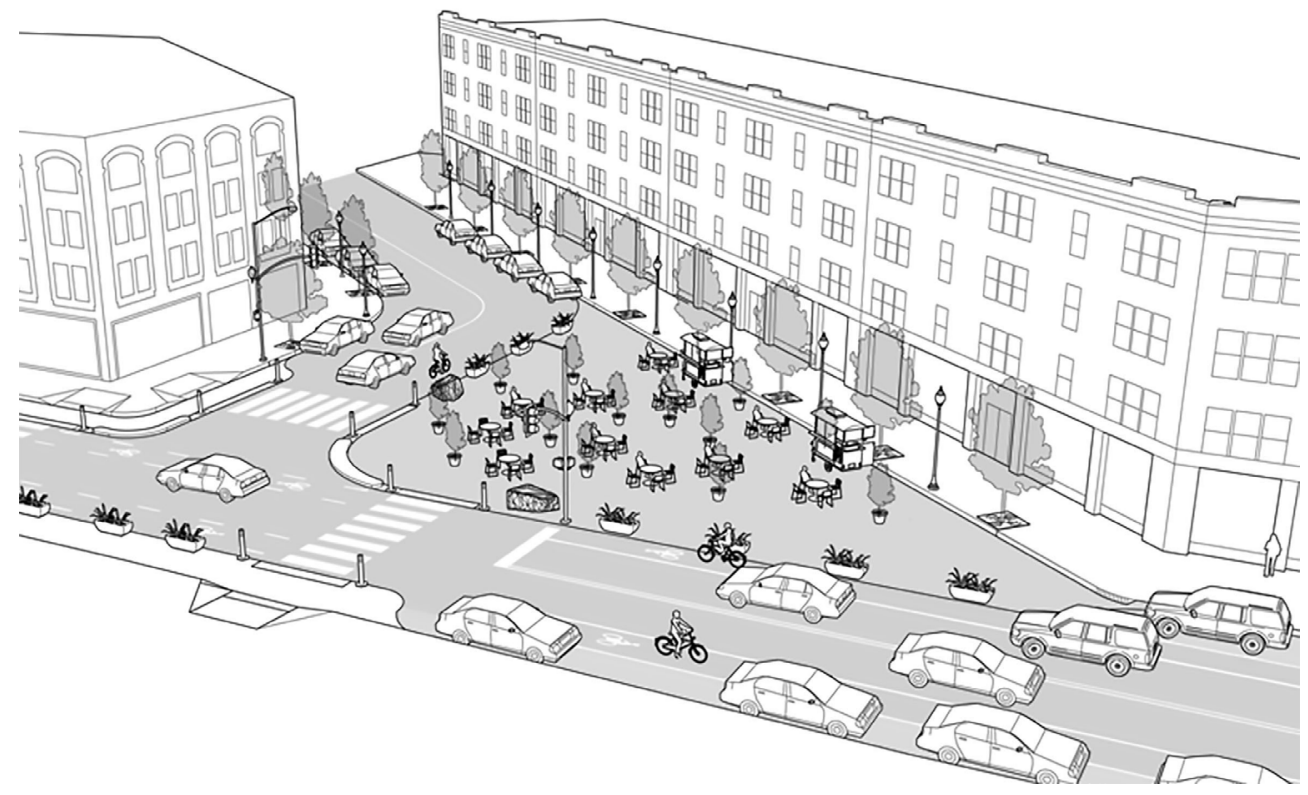

Fig. 1. Creation of temporary public spaces (source: National Association of City Transportation Officials)

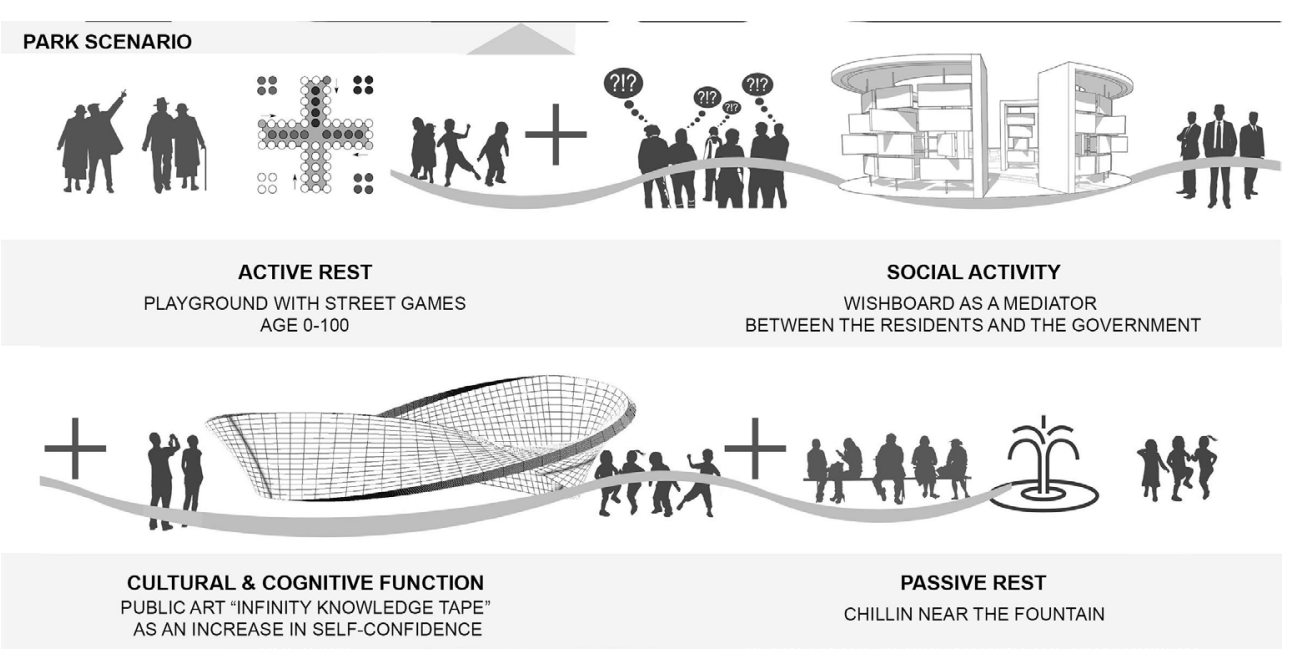

Fig. 2. Scheme for the organisation of the park in the area of Gran San Blas, Madrid, Spain - author's project proposal 


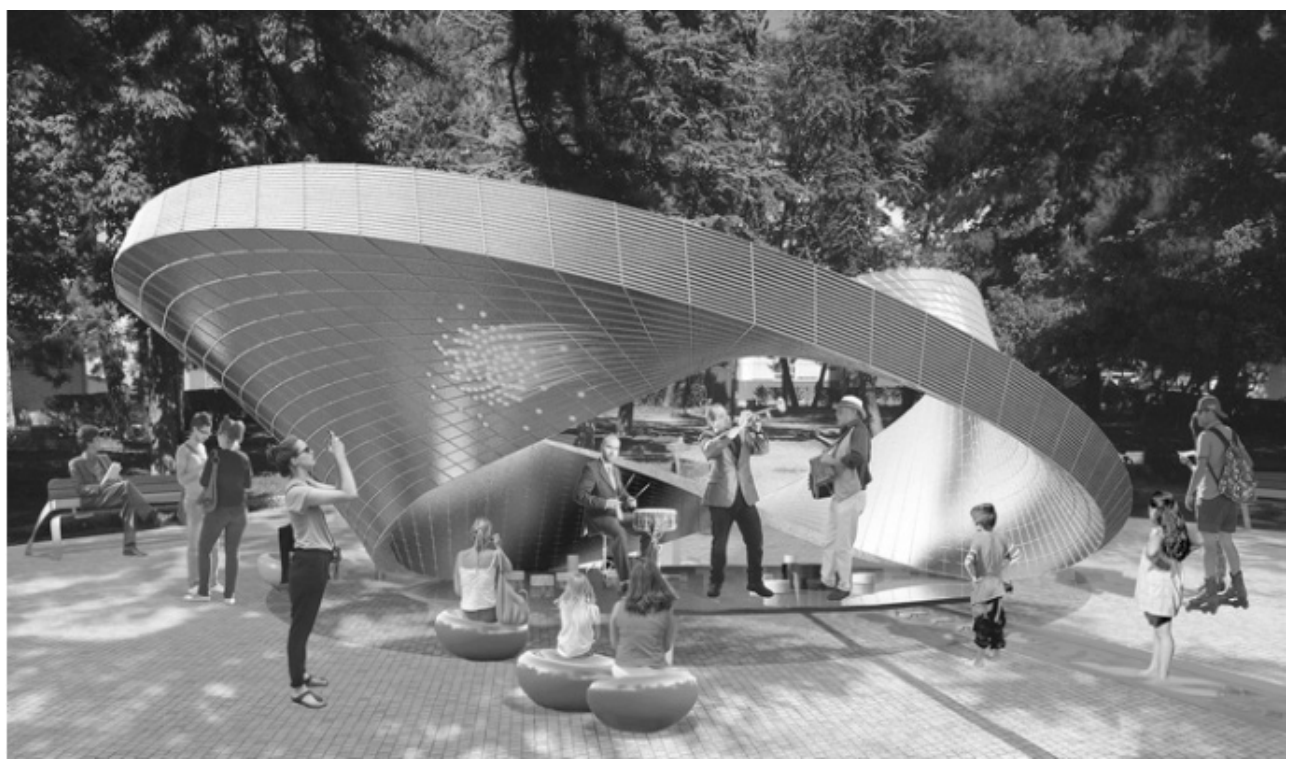

Fig.3. Example of a meme in the public urban space 'The Tape of Infinite Cognition' - author's project proposal 


\section{EDNOTES}

1 Dawkins R., The Selfish Gene, Oxford University Press, 1976, 224.

2 Derrida J., 'Speech and Phenomena' and Other Essays on Husserl's Theory of Signs. Illinois, Northwestern University Press, 1973, 166.

3 Pawlyn M., Biomimicry in Architecture, RIBA Publishing, London, 2016, 176.

4 What is Computational Design?, https://blog.ramboll.com/rcd/articles/what-is-computational-design.html

5 Synthetic biology explained, https://www.ebrc.org/what-is-synbio

6 Seamon D., Architecture and Phenomenology, Routledge, London, tentatively in 2018.

7 Introduction to Behavioral Economics, https://www.thoughtco.com/intro-to-behavioral-economics-1146878

8 Oldenburg R., Celebrating the Third Place: Inspiring Stories about the 'Great Good Places' at the Heart of Our Communities. New York, Marlowe \& Company, 2000, 345.

9 Holovatiuk A., The issue of the importance of public spaces in raising the level of well-being in the country, Innovation technologies in architecture and design: II International Scientific-practical conference, Charkiw, CHNUCA, 2018, 54-57 (in Ukrainian).

10 National Association of City Transportation Officials, https://nacto.org/publication/urban-street-design-guide/interim-design-strategies/ interim-public-plazas/.

11 Documents for contest task 2017, http:// www.isover-students.com 


\section{REFERENCES}

Dawkins R., The Selfish Gene, Oxford University Press, 1976.

Derrida J., 'Speech and Phenomena' and Other Essays on Husserl's Theory of Signs. Illinois, Northwestern University Press, 1973.

Documents for contest task 2017, http:// www.isover-students.com

Introduction to Behavioral Economics, https://www.thoughtco.com/intro-to-behavioral-economics-1146878

Holovatiuk A., The issue of the importance of public spaces in raising the level of well-being in the country, Innovation technologies in architecture and design: II International Scientific-practical conference, Charkiw, CHNUCA, 2018, 54-57 (in Ukrainian).

National Association of City Transportation Officials, https://nacto.org/publication/urbanstreet-design-guide/interim-design-strategies/ interim-public-plazas/.

Oldenburg R., Celebrating the Third Place: Inspiring Stories about the 'Great Good Places' at the Heart of Our Communities. New York, Marlowe \& Company, 2000.

Pawlyn M., Biomimicry in Architecture, RIBA Publishing, London, 2016.

Seamon D., Architecture and Phenomenology, Routledge, London, tentatively in 2018.

Synthetic biology explained, https://www.ebrc.org/what-is-synbio

What is Computational Design?, https://blog.ramboll.com/rcd/articles/what-is-computational-design.html 